\title{
Evaluation of fibroblast growth factor-2 on the proliferation of osteogenic potential and protein expression of stem cell spheroids composed of stem cells derived from bone marrow
}

\author{
JAE-YONG TAE, YOUNGKYUNG KO and JUN-BEOM PARK
}

Department of Periodontics, College of Medicine, The Catholic University of Korea, Seoul 06591, Republic of Korea

Received October 23, 2018; Accepted April 18, 2019

DOI: $10.3892 /$ etm.2019.7543

\begin{abstract}
Fibroblast growth factor-2 (FGF-2) is reported to have various functions and is considered a key human mesenchymal stem cell mitogen, often supplemented to increase human mesenchymal stem cell growth rates. The purpose of this study was to evaluate the effects of FGF-2 on cellular viability and osteogenic differentiation using three-dimensional cell spheroids of stem cells. Three-dimensional cell spheroids were fabricated using concave silicon elastomer-based microwells in the presence of FGF-2 at concentrations of 0 , 30, 60 and $90 \mathrm{ng} / \mathrm{ml}$. Qualitative cellular viability was determined with a confocal microscope, and quantitative cellular viability was evaluated using a Cell Counting Kit-8 assay. Alkaline phosphatase activity and Alizarin Red S staining were used to assess osteogenic differentiation. Spheroids were well formed in silicon elastomer-based concave microwells on Day 1. The average spheroid diameters at Day 1 for FGF-2 at 0,30, 60 and $90 \mathrm{ng} / \mathrm{ml}$ were 202.2 $\pm 3.0,206.6 \pm 22.6,208.8 \pm 6.8$ and 196.6 $\pm 26.7 \mu \mathrm{m}$, respectively ( $\mathrm{P}>0.05)$. The majority of the cells in the cell spheroids emitted green fluorescence. The relative Cell Counting Kit-8 assay values for FGF-2 at 0, 30, 60 and $90 \mathrm{ng} / \mathrm{ml}$ at Day 1 were 100.0 $\pm 5.5,101.8 \pm 8.8,99.2 \pm 4.8$ and $103.4 \pm 9.6 \%(\mathrm{P}>0.05)$. The addition of FGF-2 at $60 \mathrm{ng} / \mathrm{ml}$ concentration produced the highest value for alkaline phosphatase activity. Mineralized extracellular deposits were evenly observed in each group, and the highest value was identified for FGF-2 groups at $60 \mathrm{ng} / \mathrm{ml}$ concentration for Alizarin Red S staining. Based on these findings, it was concluded that FGF-2 may increase alkaline phosphatase activity or Alizarin Red S staining, and further studies are needed to fully elucidate the mechanisms of FGF-2.
\end{abstract}

Correspondence to: Professor Jun-Beom Park, Department of Periodontics, College of Medicine, The Catholic University of Korea, 222 Banpo-daero, Seocho-gu, Seoul 06591, Republic of Korea E-mail: jbassoonis@yahoo.co.kr

Key words: bone marrow, cell survival, cell differentiation, cellular spheroids, fibroblast growth factors, osteogenesis, stem cells

\section{Introduction}

Fibroblast growth factor-2 (FGF-2) is reported to have various functions and serve numerous regulatory functions in complex organisms (1). FGF-2 is reported to protect cells from various forms of death, such as apoptosis or necrosis through inhibition of autophagy (2) and implicated in satellite cell self-renewal and differentiation (3). FGF-2 is a key human mesenchymal stem cell mitogen, often supplemented to increase human mesenchymal stem cell growth rates (4). The pro-survival effect of FGF-2 was seen from apoptotic cell death (5). Suppression of FGF-2 expression inhibited neural stem cell proliferation (6), and preconditioning with FGF-2 significantly increased production of the periodontal stem cells' angiogenic secretome, especially vascular endothelial growth factor and placental growth factor secretion (7).

Moreover, FGF-2 has been involved in the differentiation of tested cells. FGF-2 was associated with accelerated dedifferentiation during expansion culture and superior re-differentiation upon induction (8). Fully dedifferentiated chondrocytes expanded in a specific mesenchymal stem cell growth medium with FGF-2 obtained the mesenchymal stem cell phenotype in an in vitro environment (8). However, in an in vivo environment, fully dedifferentiated chondrocytes retained the chondrocyte phenotype. FGF-2 is an important neurotrophic factor that can stimulate neurogenesis and angiogenesis, and has been shown to have neuroprotective effects after brain injuries (2).

In recent years, a cell spheroid culture system using stem cells has been used for cell therapy (9). These stem-cell spheroids were shown to maintain stem cell characteristics and differentiation ability (10). This study was performed to evaluate the effects of FGF-2 on cellular viability and osteogenic differentiation using three-dimensional cell spheroids of stem cells.

\section{Materials and methods}

Three-dimensional cultures of human bone marrow-derived stem cells. The Institutional Review Board (Seoul St Mary's Hospital, College of Medicine, The Catholic University of Korea) reviewed and approved the present work (KC18SESI0083), and all of the experimental schemes used were performed according to relevant guidelines. Human mesenchymal stem cells derived from bone marrow (BMSCs, Catholic MASTER Cells) were procured from the Catholic Institute of Cell Therapy (CIC). The 
Catholic MASTER Cells supplied by Catholic Institute of Cell Therapy were derived from human bone marrow donated by healthy donors after informed consent was obtained. Isolation and propagation of the BMSCs were performed following a previously reported method (11). The Catholic Institute of Cell Therapy has verified that all the samples showed CD73 and CD90 expression was $>90 \%$ positive. The cells were plated on the culture dish, and cells that were detached from the dish were eliminated. The culture medium was refreshed every 2 or 3 days, and the BMSCs were nurtured with $95 \% \mathrm{O}_{2}$ and $5 \% \mathrm{CO}_{2}$ at $37^{\circ} \mathrm{C}$ in the incubator.

Fig. 1 shows the overview of the study design. Six mouth rinses were applied for this study. We used silicon elastomer-based concave microwells (H389600, StemFIT 3D; MicroFIT) with $600 \mu \mathrm{m}$ diameters to make stem cell spheroids. A total of $1 \times 10^{6}$ cells were loaded into each well and cultured to evaluate the cell response. Cell spheroids made of bone marrow-derived stem cells were treated with FGF-2 at 0, 30, 60 and $90 \mathrm{ng} / \mathrm{ml}$ concentration. The spheroids' changes in morphology were evaluated using an inverted microscope (Leica DMIRM; Leica Microsystems). The changes in the spheroids' diameter were evaluated on Days 1,3, 5, and 7.

Determination of cellular viability. Stem cell spheroids were cultured in growth media composed of an alpha-minimal essential medium ( $\alpha$-MEM; Gibco; Thermo Fisher Scientific, Inc.) comprising $200 \mathrm{mM}$ of L-Glutamine, $10 \mathrm{mM}$ of ascorbic acid 2-phosphate, $100 \mu \mathrm{g} / \mathrm{ml}$ of streptomycin (all from Sigma-Aldrich; Merck KGaA), 15\% fetal bovine serum (Gibco; Thermo Fisher Scientific, Inc.; $100 \mathrm{U} / \mathrm{ml}$ of penicillin, $2 \mathrm{mg} / \mathrm{ml}$ of glycerophosphate disodium salt hydrate, and $38 \mu \mathrm{g} / \mathrm{ml}$ of dexamethasone.

Qualitative analysis for cellular viability was done using the commercially available Live/Dead Kit assay (Molecular Probes) on Day 7. In short, these spheroids were washed twice with the growth media, followed by suspension in $1 \mathrm{ml}$ of $\alpha$-MEM containing $2 \mu \mathrm{l}$ of $50 \mathrm{mM}$ calcein acetoxymethyl ester working solution and $4 \mu \mathrm{l}$ of $2 \mathrm{mM}$ ethidium homodimer- 1 for $30 \mathrm{~min}$ at room temperature. The intracellular esterase makes non-fluorescent, cell-permeant calcein acetoxymethyl ester in intact cells to produce green fluorescence. The ethidium homodimer enters the damaged cells and produces a red fluorescence. We observed the spheroids stained with calcein acetoxymethyl ester and ethidium homodimer-1 using a fluorescence microscope (Axiovert 200; Zeiss).

The commercially available cell counting kit-8 (CCK-8; Dojindo) was used for the quantitative analysis of cell viability on Days 1, 3, 5, and 7. WST-8 [2-(2-methoxy-4-nitropheny 1)-3-(4-nitrophenyl)-5-(2,4-disulfophenyl)-2H tetrazolium, monosodium salt] was added and the stem cell spheroids were cultured for $45 \mathrm{~min}$ at $37^{\circ} \mathrm{C}$. The absorbance of the samples was spectrophotometrically measured at $450 \mathrm{~nm}$ using a microplate reader (BioTek).

Alkaline phosphatase activity assays and Alizarin Red $S$ staining. Cell spheroids grown on culture plates with osteogenic media composed of $\alpha$-MEM (Gibco; Thermo Fisher Scientific, Inc.), containing $200 \mathrm{mM}$ of L-Glutamine, $10 \mathrm{mM}$ of ascorbic acid 2-phosphate, $100 \mu \mathrm{g} / \mathrm{ml}$ of streptomycin (all from Sigma-Aldrich; Merck KGaA), 15\% fetal bovine serum (Gibco;
Thermo Fisher Scientific, Inc.), $100 \mathrm{U} / \mathrm{ml}$ of penicillin, $2 \mathrm{mg} / \mathrm{ml}$ of glycerophosphate disodium salt hydrate, and $38 \mu \mathrm{g} / \mathrm{ml}$ of dexamethasone, were obtained on Days 1, 3, and 7. We used a commercially available kit (K412-500; BioVision, Inc.) for the evaluation of alkaline phosphatase activity. The cells were suspended again with an assay buffer, sonicated, and then centrifuged to remove insoluble material. The mixture of supernatant and a p-nitrophenylphosphate substrate was incubated at $25^{\circ} \mathrm{C}$ for $40 \mathrm{~min}$. The resultant p-nitrophenol was spectrophotometrically measured at $405 \mathrm{~nm}$.

On Days 13, the stem cell spheroids were washed twice with phosphate-buffered saline (Welgene, Gyeongsan-si, Gyeongsangbuk-do, Republic of Korea), fixed with 4\% paraformaldehyde, and washed with deionized water. The cultures were then stained with Alizarin Red S for $30 \mathrm{~min}$ at room temperature. Evaluation of the morphology was then performed using an inverted microscope (Leica DM IRM). Before removing nonspecifically-bound stains, the cultures were washed three times with deionized water. Quantification was done by solubilizing the bound dye using $10 \mathrm{mM}$ sodium phosphate containing $10 \%$ cetylpyridinium chloride and evaluated spectrophotometrically at $560 \mathrm{~nm}$.

Statistical analysis. The data were shown as means \pm standard deviations of the experiments. A test of normality and the equal of variances in the samples were conducted. Two-way analysis of variance test with Tukey's post hoc test was used to assess statistical differences between the test groups and the control groups with different time-points using the statistical program SPSS 12 for Windows (SPSS Inc.). Statistical significance was set at $\mathrm{P}<0.05$.

\section{Results}

Formation of cell spheroids with human gingiva-derived stem cells. Spheroids were well formed in silicon elastomer-based concave microwells on Day 1 (Fig. 2). No significant morphological change of the cell spheroids cultured in growth media was observed after the addition of FGF-2 at 10 and $100 \mathrm{ng} / \mathrm{ml}$ concentration. The morphology results of Days 3, 5, and 7 are shown in Fig. 1, and no noticeable changes were noted with longer incubation time.

The average spheroid diameters at Day 1 for FGF-2 at 0 , 10 and $100 \mathrm{ng} / \mathrm{ml}$ were 202.2 $\pm 3.0,206.6 \pm 22.6,208.8 \pm 6.8$ and 196.6 $\pm 26.7 \mu \mathrm{m}$, respectively $(\mathrm{P}>0.05)$ (Fig. 3). The average spheroid diameters at Day 3 were $213.1 \pm 20.3$, 202.5 \pm 22.3 , $167.2 \pm 3.9$ and $177.6 \pm 6.3 \mu \mathrm{m}$, respectively $(\mathrm{P}>0.05)$. The values for Day 5 were $148.7 \pm 13.5,148.8 \pm 18.1,181.0 \pm 15.5$ and $163.7 \pm 3.7 \mu \mathrm{m}$, respectively $(\mathrm{P}>0.05)$. The average diameters at Day 7 were $170.8 \pm 12.0,166.6 \pm 12.7,160.0 \pm 9.8$ and $145.9 \pm 5.2 \mu \mathrm{m}$, respectively $(\mathrm{P}>0.05)$.

Determination of cellular viability. The qualitative results of viability of cell spheroids were analyzed using a Live/Dead Kit assay at Day 7 (Fig. 4). In all cases, most of the cells in the cell spheroids emitted green fluorescence.

The quantitative value for cellular viability on Days 1, 3, 5, and 7 is shown in Fig. 5. The relative Cell Counting Kit-8 assay values for FGF-2 at $0,30,60$, and $90 \mathrm{ng} / \mathrm{ml}$ at Day 1 were $100.0 \pm 5.5,101.8 \pm 8.8,99.2 \pm 4.8$ and $103.4 \pm 9.6 \%$, respectively. 


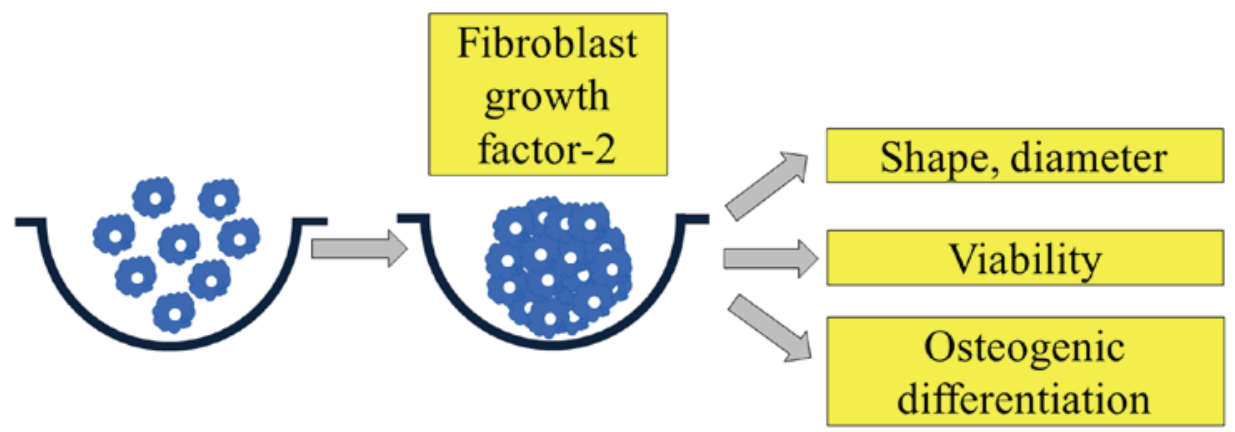

Figure 1. Diagram showing the overview of the study design.

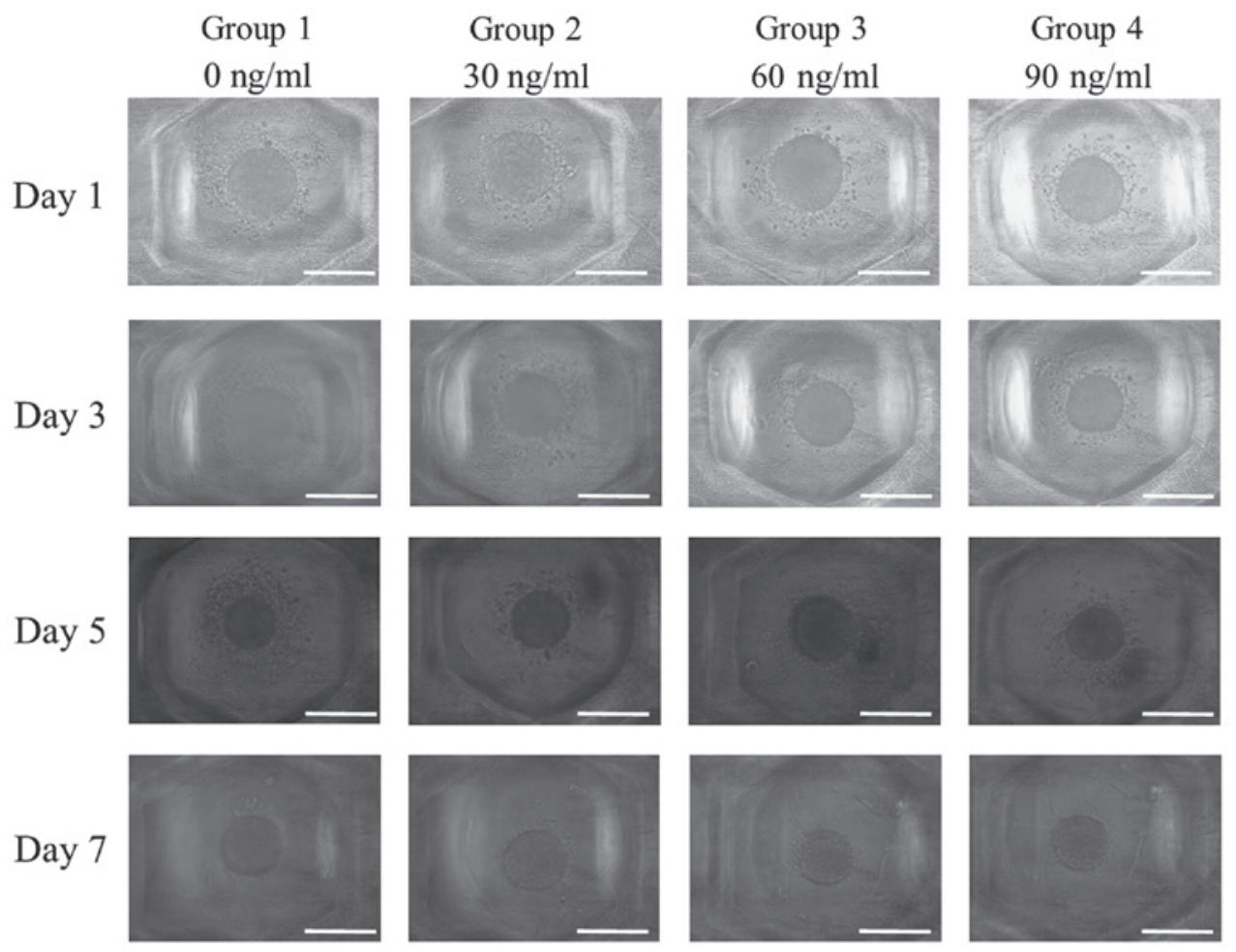

Figure 2. Morphology of the stem-cell spheroids at Days 1,3,5 and 7. Scale bar, $200 \mu \mathrm{m}$. Magnification, x100.

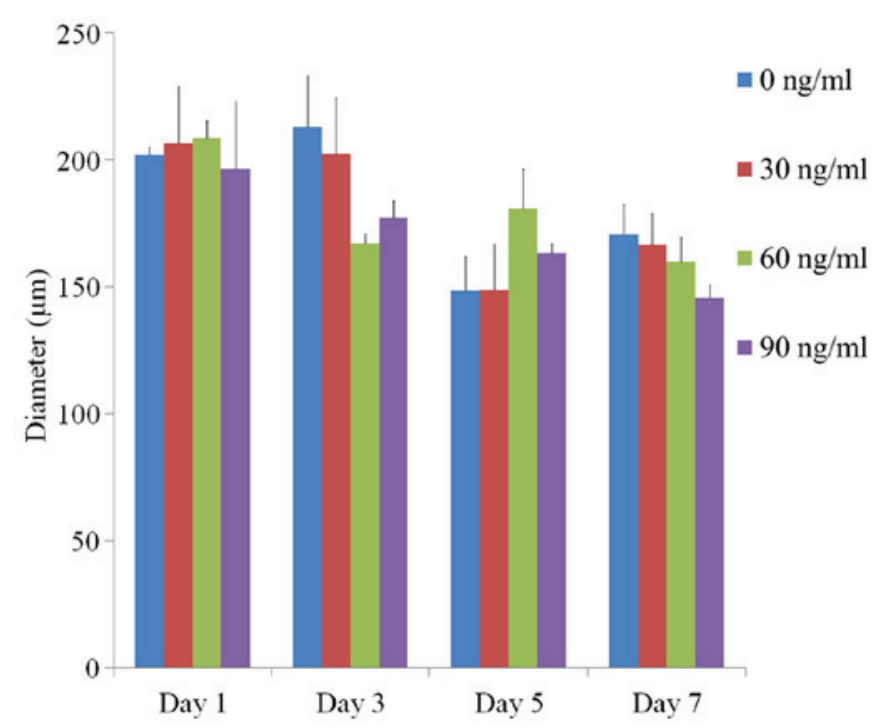

Figure 3. Diameter of the spheroids at Days 1,3,5 and 7.
There were no statistically significant differences between the groups on Day 1 ( $\mathrm{P}>0.05)$. Significant differences were noted between the groups with longer incubation time in each group $(\mathrm{P}<0.05)$.

Alkaline phosphatase activity assays and Alizarin Red $S$ staining. The results of the alkaline phosphatase activity assays at Days 1, 3,5, and 7 are shown in Fig. 6. The absorbance values at $405 \mathrm{~nm}$ at Day 7 for groups $1,2,3$, and 4 were $0.422 \pm 0.005$, $0.420 \pm 0.008,0.492 \pm 0.005$ and $0.397 \pm 0.028$, respectively. The highest value was noted for FGF-2 groups at $60 \mathrm{ng} / \mathrm{ml}$ concentration, but this did not reach the statistical significance $(\mathrm{P}>0.05)$.

The results of the mineralization assay at Day 13 are shown in Fig. 7. Mineralized extracellular deposits were evenly noted in each group. The absorbance values at $405 \mathrm{~nm}$ at Day 13 for groups $1,2,3$, and 4 were $0.079 \pm 0.005,0.089 \pm 0.004$, $0.097 \pm 0.010$ and $0.087 \pm 0.002$, respectively. The quantification results showed that the highest value was noted for FGF-2 groups at $60 \mathrm{ng} / \mathrm{ml}$ concentration when compared with the value of the 


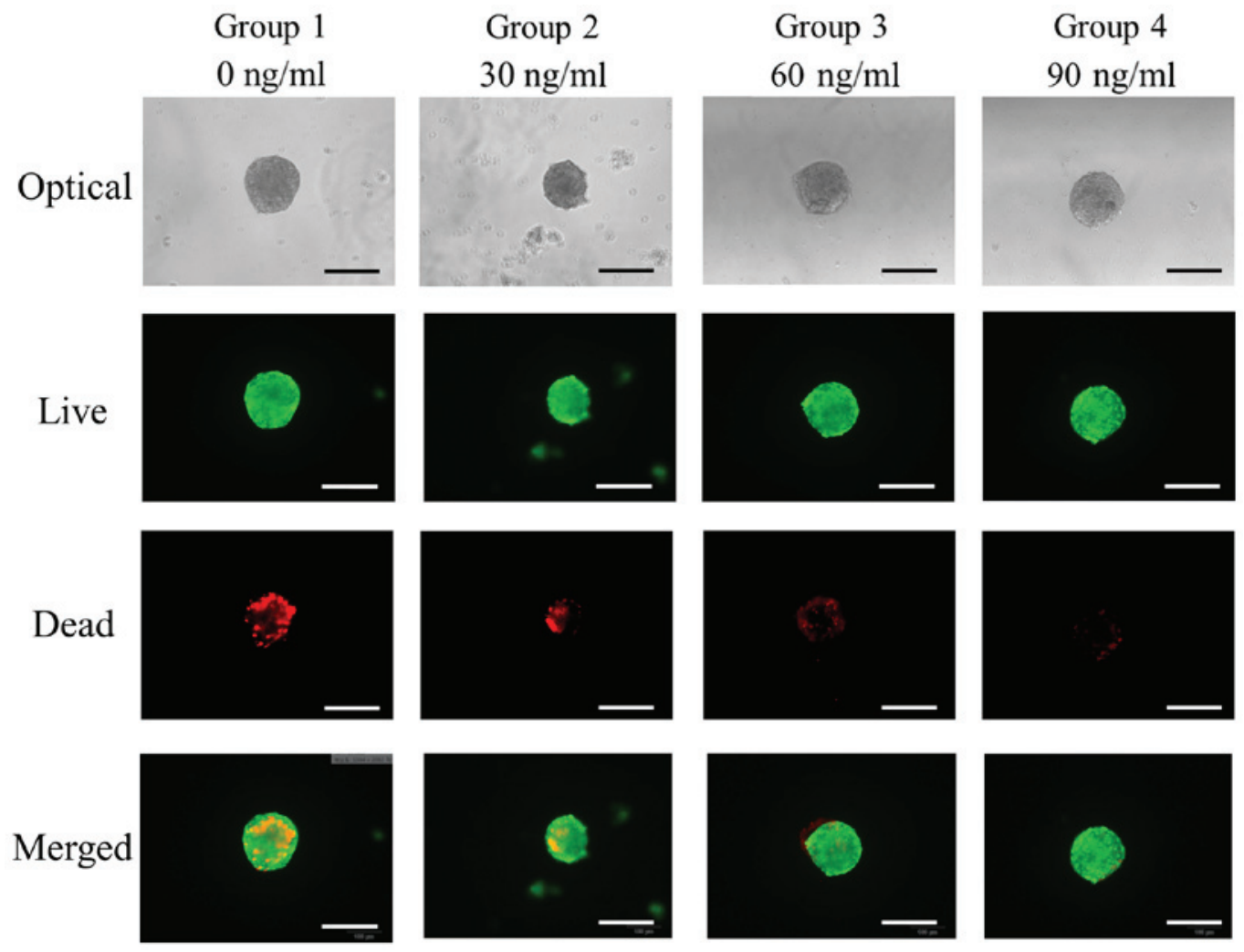

Figure 4. Optical, live and dead cell images of stem cell spheroids at Day 7. Scale bar, $100 \mu \mathrm{m}$. Magnification, x200.

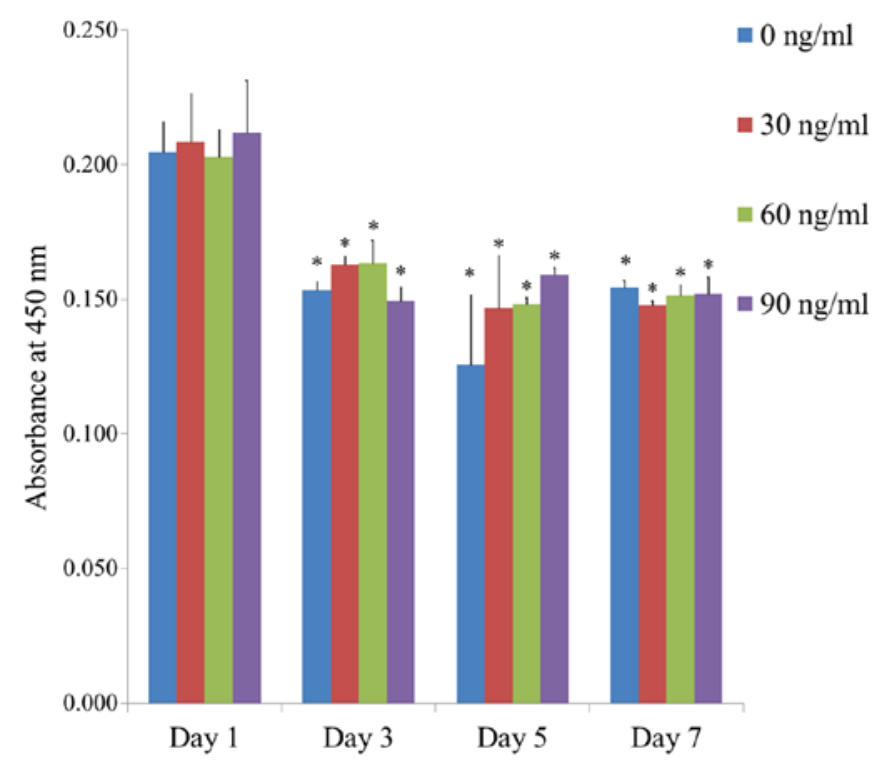

Figure 5. Cellular viability using Cell Counting Kit-8 on Days 1, 3, 5, and 7. ${ }^{*} \mathrm{P}<0.05$ vs. respective group on Day 1.

control, but this did not reach the statistical significance (Fig. 8) $(\mathrm{P}>0.05)$.

\section{Discussion}

This report discusses the effects of FGF-2 on cellular viability and osteogenic differentiation using cell spheroids of stem cells. The application of FGF-2 increased alkaline phosphatase activity or Alizarin Red S staining at $60 \mathrm{ng} / \mathrm{ml}$ concentration.

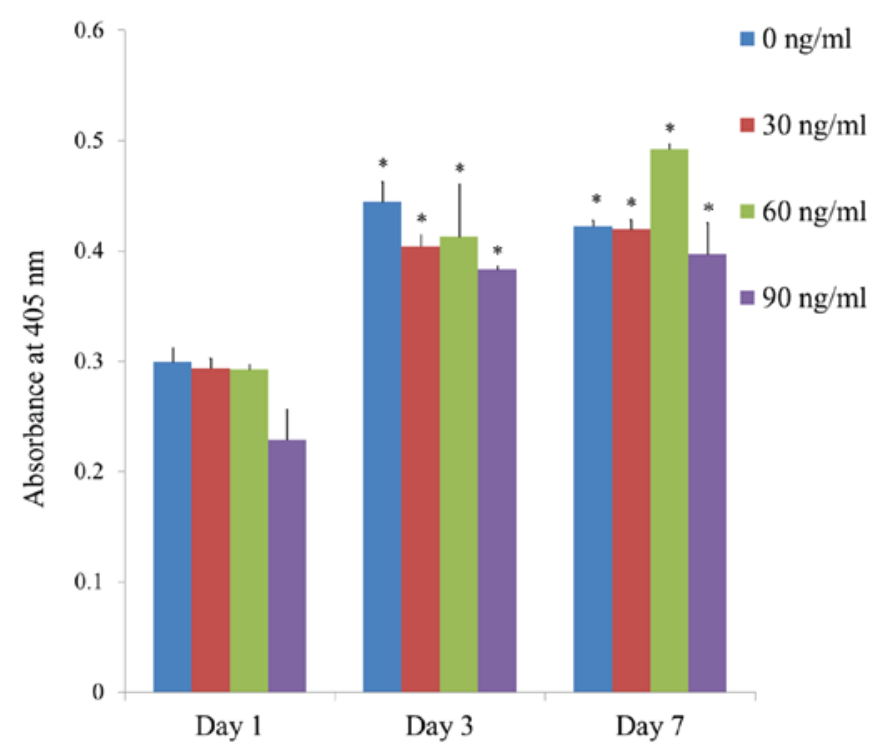

Figure 6. Alkaline phosphatase activity on Days 1,3 , and $7 .{ }^{*} \mathrm{P}<0.05$ vs. respective group on Day 1.

Previous reports showed that FGF-2 induced cell proliferation, survival, migration, and differentiation in various cell types and tissues, and FGF-2 has been applied for clinical use in the regeneration of damaged tissues (12). FGF-2 played an important role in promoting wound healing and reducing scar tissue (13), and was suggested to be a potential therapeutic agent for improving stem cell-based approaches for the treatment of diabetes mellitus and its complications (14). Synergistic actions of FGF-2 and bone 

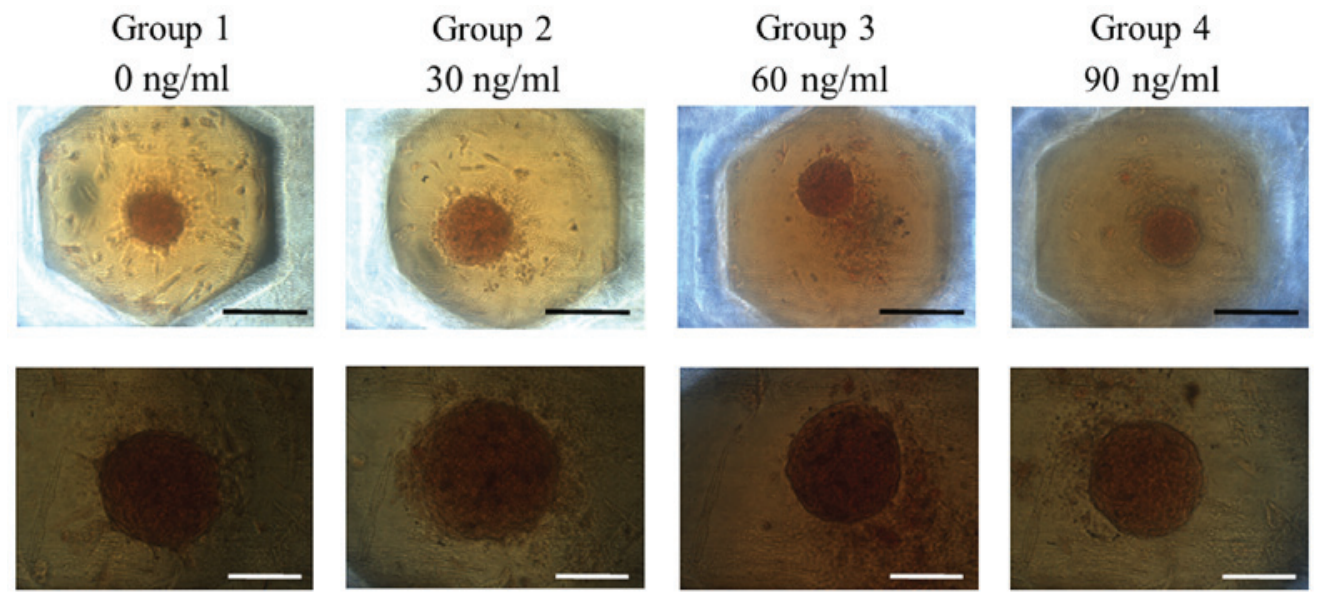

Figure 7. Results of Alizarin Red S staining on Day 13. Upper panel: Scale bar, $200 \mu \mathrm{m}$; magnification, x100. Lower panel: Scale bar, $100 \mu \mathrm{m}$; Magnification, x100.

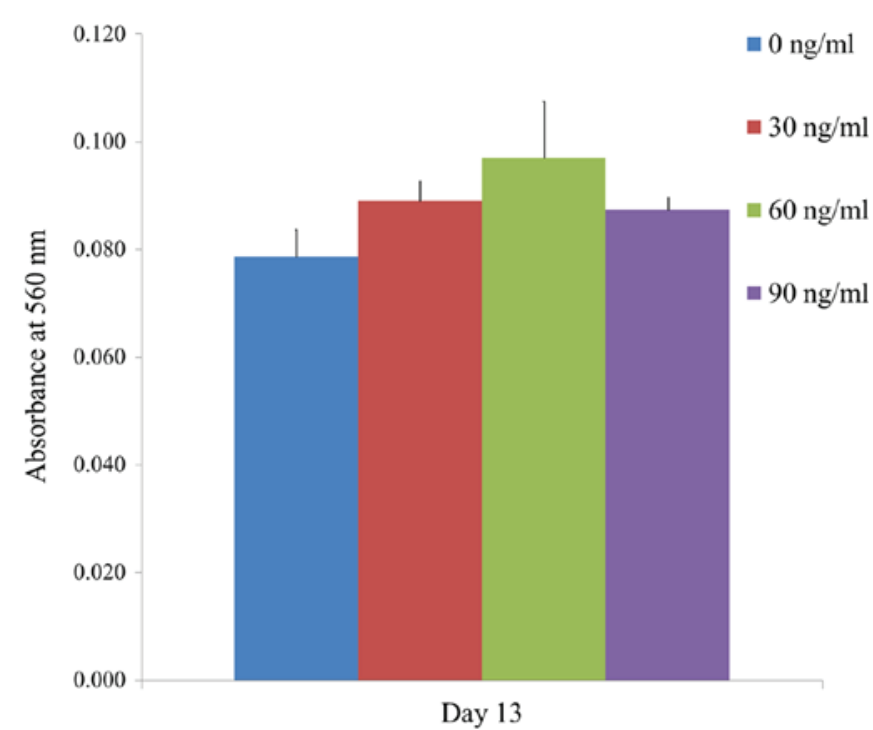

Figure 8. Quantification results of Alizarin Red S staining on Day 13.

marrow transplantation mitigate radiation-induced intestinal injury (15).

Controversial results have been reported on cell differentiation. Recombinant human FGF-2 inhibited osteogenic induction and mineralization in human periodontal ligament-derived cells (12). FGF-2 is reported to show an antagonistic effect on the hard tissue differentiation induced by bone morphogenetic protein-2 and bone morphogenetic protein-4 (16). Suppression of FGF-2 expression inhibited neural stem cell differentiation (6). In another report, FGF-2 regulated and supported osteoblastic niche cells during hematopoietic homeostasis recovery after bone marrow suppression (17). The stimulatory effects of FGF-2 signaling were seen on odontoblast differentiation from early progenitors in dental pulp (18). There has been efficient generation of neurons from human bone marrow derived mesenchymal stem cells using FGF-2 alone (19).

Previous reports have attempted to reveal the mechanisms of FGF-2. FGF-2 induced proliferative action, dependent on SK1 and SK2, as well as xphingosine 1-phosphate and sphingosine kinase (5). FGF-2 reduced scar tissue by inhibiting the differentiation of epidermal stem cells to myofibroblasts via the Notch1/Jagged1 pathway (13). FGF-2 shows the effects by repressing MyoD, and Linc-RAM is required for FGF-2 function in regulating myogenic cell differentiation (3). FGF-2 acts due to suppression of endocytoplasmic reticulum stress (20).

Combination therapy is used for the application of FGF-2. Dual delivery of FGF-2 and nerve growth factor coacervater ameliorates diabetic peripheral neuropathy via inhibiting Schwann cells apoptosis (20). When accompanied by connective tissue growth factor, FGF-2 has a slightly additive effect on fibrogenic differentiation of mesenchymal stem cells (21). Adenovirus-mediated expression of FGF-2 and bone morphogenetic protein-2 in bone marrow-derived mesenchymal stem cells, combined with a demineralized bone matrix, was applied for repair of femoral head osteonecrosis by promoting bone formation and angiogenesis (22). Combined delivery of FGF-2, transforming growth factor- $\beta 1$, and adipose-derived stem cells from an engineered periosteum to a critical-sized mouse femur defect yielded improved bone allograft healing (23). The concurrent application of hypoxia and FGF-2 could provide a favorable condition for culturing human bone marrow-derived stem cells to be used in clinical applications associated with bone tissue engineering, due to the enhancement of cellular proliferation and regenerative potential (24). The effects of temporal manipulation were achieved by applying FGF-2 and transforming growth factor- $\beta 3$ on the derivation of proliferative chondrocytes from mesenchymal stem cells (25).

Based on these findings, it was concluded that FGF-2 could produce increased alkaline phosphatase activity or Alizarin Red S staining and further studies are needed to elucidate the mechanisms of FGF-2.

\section{Acknowledgements}

Not applicable.

\section{Funding}

The present study was supported by Basic Science Research Program through the National Research Foundation of Korea funded by the Ministry of Science, Information and 
Communication Technology and Future Planning (grant no. NRF-2017R1A1A1A05001307).

\section{Availability of data and materials}

All data generated or analyzed during this study are included in the published article.

\section{Authors' contributions}

JYT, YK and JBP designed the study, were responsible for data access and analysis, performed the experiments and wrote the manuscript. All authors read and approved the final manuscript.

\section{Ethics approval and consent to participate}

The present study was approved by the Institutional Review Board at Seoul St Mary's Hospital, College of Medicine, and The Catholic University of Korea (approval no. KC18SESI0083). Informed consent was obtained from the participants as specified in the Declaration of Helsinki and all of the experimental schemes were performed according to the relevant guidelines as specified in the Declaration of Helsinki.

\section{Patient consent for publication}

Not applicable.

\section{Competing interests}

The authors declare that they have no competing interests.

\section{References}

1. Dvorak P, Bednar D, Vanacek P, Balek L, Eiselleova L, Stepankova V, Sebestova E, Kunova Bosakova M, Konecna Z, Mazurenko S, et al: Computer-assisted engineering of hyperstable fibroblast growth factor 2. Biotechnol Bioeng 115: 850-862, 2018.

2. Tang C, Shan Y, Hu Y, Fang Z, Tong Y, Chen M, Wei X, Fu X and $\mathrm{Xu}$ X: FGF2 attenuates neural cell death via suppressing autophagy after rat mild traumatic brain injury. Stem Cells Int 2017: 2923182, 2017.

3. Zhao Y, Cao F, Yu X, Chen C, Meng J, Zhong R, Zhang Y and Zhu D: Linc-RAM is required for FGF2 function in regulating myogenic cell differentiation. RNA Biol 15: 404-412, 2018.

4. Titmarsh DM, Tan CL, Glass NR, Nurcombe V, Cooper-White JJ and Cool SM: Microfluidic screening reveals heparan sulfate enhances human mesenchymal stem cell growth by modulating fibroblast growth factor-2 transport. Stem Cells Transl Med 6 : 1178-1190, 2017.

5. Bruno M, Rizzo IM, Romero-Guevara R, Bernacchioni C, Cencetti F, Donati C and Bruni P: Sphingosine 1-phosphate signaling axis mediates fibroblast growth factor 2-induced proliferation and survival of murine auditory neuroblasts. Biochim Biophys Acta 1864: 814-824, 2017.

6. Li C, Che LH, Shi L and Yu JL: Suppression of basic fibroblast growth factor expression by antisense oligonucleotides inhibits neural stem cell proliferation and differentiation in rat models with focal cerebral infarction. J Cell Biochem 118: 3875-3882, 2017.

7. Ratajczak J, Hilkens P, Gervois P, Wolfs E, Jacobs R, Lambrichts I and Bronckaers A: Angiogenic capacity of periodontal ligament stem cells pretreated with deferoxamine and/or fibroblast growth factor-2. PLoS One 11: e0167807, 2016.

8. Lee J, Lee JY, Chae BC, Jang J, Lee E and Son Y: Fully dedifferentiated chondrocytes expanded in specific mesenchymal stem cell growth medium with FGF2 obtains mesenchymal stem cell phenotype in vitro but retains chondrocyte phenotype in vivo. Cell Transplant 26: 1673-1687, 2017.
9. Lee SI, Yeo SI, Kim BB, Ko Y and Park JB: Formation of size-controllable spheroids using gingiva-derived stem cells and concave microwells: Morphology and viability tests. Biomed Rep 4: 97-101, 2016.

10. Lee SI, Ko Y and Park JB: Evaluation of the maintenance of stemness, viability, and differentiation potential of gingiva-derived stem-cell spheroids. Exp Ther Med 13: 1757-1764, 2017.

11. Jeong $\mathrm{CH}$, Kim SM, Lim JY, Ryu CH, Jun JA and Jeun SS: Mesenchymal stem cells expressing brain-derived neurotrophic factor enhance endogenous neurogenesis in an ischemic stroke model. Biomed Res Int 2014: 129145, 2014.

12. Lee JH, Lee JE, Kang KJ and Jang YJ: Functional efficacy of human recombinant FGF-2s tagged with (His) ${ }_{6}$ and (His-Asn) ${ }_{6}$ at the $\mathrm{N}$ - and $\mathrm{C}$-termini in human gingival fibroblast and periodontal ligament-derived cells. Protein Expr Purif 135: 37-44, 2017.

13. Wang P, Shu B, Xu Y, Zhu J, Liu J, Zhou Z, Chen L, Zhao J, Liu X, Qi S, et al: Basic fibroblast growth factor reduces scar by inhibiting the differentiation of epidermal stem cells to myofibroblasts via the Notch1/Jagged1 pathway. Stem Cell Res Ther 8: 114, 2017.

14. Nawrocka D, Kornicka K, Szydlarska J and Marycz K: Basic fibroblast growth factor inhibits apoptosis and promotes proliferation of adipose-derived mesenchymal stromal cells isolated from patients with type 2 diabetes by reducing cellular oxidative stress. Oxid Med Cell Longev 2017: 3027109, 2017.

15. Kim BH, Jung HW, Seo SH, Shin H, Kwon J and Suh JM: Synergistic actions of FGF2 and bone marrow transplantation mitigate radiation-induced intestinal injury. Cell Death Dis 9: 383, 2018.

16. Hyun SY, Lee JH, Kang KJ and Jang YJ: Effect of FGF-2, TGF- $\beta-1$, and BMPs on teno/ligamentogenesis and osteo/cementogenesis of human periodontal ligament stem cells. Mol Cells 40: 550-557, 2017.

17. Yoon KA, Son Y, Choi YJ, Kim JH and Cho JY: Fibroblast growth factor 2 supports osteoblastic niche cells during hematopoietic homeostasis recovery after bone marrow suppression. Cell Commun Signal 15: 25, 2017.

18. Vidovic-Zdrilic I, Vining KH, Vijaykumar A, Kalajzic I, Mooney DJ and Mina M: FGF2 enhances odontoblast differentiation by $\alpha \mathrm{SMA}(+)$ progenitors in vivo. J Dent Res 97: 1170-1177, 2018.

19. Singh M, Kakkar A, Sharma R, Kharbanda OP, Monga N, Kumar M, Chowdhary S, Airan B and Mohanty S: Synergistic effect of BDNF and FGF2 in efficient generation of functional dopaminergic neurons from human mesenchymal stem cells. Sci Rep 7: 10378, 2017.

20. Li R, Ma J, Wu Y, Nangle M, Zou S, Li Y, Yin J, Zhao Y, Xu H, Zhang $\mathrm{H}$, et al: Dual delivery of NGF and bFGF coacervater ameliorates diabetic peripheral neuropathy via inhibiting schwann cells apoptosis. Int J Biol Sci 13: 640-651, 2017.

21. Xu R,ZhaoH, Muhammad H,Dong M, Besenbacher F and Chen M: Dual-delivery of FGF-2/CTGF from silk fibroin/PLCL-PEO coaxial fibers enhances MSC proliferation and fibrogenesis. Sci Rep 7: 8509, 2017.

22. Peng WX and Wang L: Adenovirus-mediated expression of BMP-2 and BFGF in bone marrow mesenchymal stem cells combined with demineralized bone matrix for repair of femoral head osteonecrosis in beagle dogs. Cell Physiol Biochem 43: 1648-1662, 2017.

23. Romero R, Travers JK, Asbury E, Pennybaker A, Chubb L, Rose R, Ehrhart NP and Kipper MJ: Combined delivery of FGF-2, TGF- $\beta 1$, and adipose-derived stem cells from an engineered periosteum to a critical-sized mouse femur defect. J Biomed Mater Res A 105: 900-911, 2017.

24. Lee JS, Kim SK, Jung BJ, Choi SB, Choi EY and Kim CS: Enhancing proliferation and optimizing the culture condition for human bone marrow stromal cells using hypoxia and fibroblast growth factor-2. Stem Cell Res 28: 87-95, 2018.

25. Tay LM, Wiraja C, Wu Y, Yang Z, Lee EH and Xu C: The effect of temporal manipulation of transforming growth factor beta 3 and fibroblast growth factor 2 on the derivation of proliferative chondrocytes from mensenchymal stem cells-A study monitored by quantitative reverse transcription polymerase chain reaction and molecular beacon based nanosensors. J Biomed Mater Res A 106: 895-904, 2018.

This work is licensed under a Creative Commons Attribution-NonCommercial-NoDerivatives 4.0 International (CC BY-NC-ND 4.0) License. 